\title{
BERGERAK UNTUK SEHAT
}

Oleh: Soni Nopembri

Dosen Jurusan Pendidikan Olahraga FIK UNY

\section{Abstrak}

Judul dalam tulisan menjadi dasar pemikiran sederhana mengenai hubungan antara aktivitas jasmani dan kesehatan. Tulisan ini juga memberikan konsep dasar yang sangat sederhana hubungannya dengan pengaruh melakukan aktivitas jasmani pada peningkatan dan pemeliharaan kesehatan tubuh.

Makna mengenai kesehatan secara filosofis akan memberikan gambaran begitu pentingnya kesehatan bagi seorang manusia. Berbagai manfaat yang secara nyata didapat dari melakukan aktivitas jasmani yang teratur digambarkan secara sederhana pada bagian kedua tulisan ini. Peningkatan dan pemeliharaan kesehatan merupakan tujuan utama manusia melakukan aktivitas jasmani secara teratur. Aktivitas jasmani sederhana yang dapat dilakukan untuk meningkatkan dan memeliharaan kesehatan dibahas dalam bagian ini. Pembahasan juga menyangkut pentingnya aktivitas jasmani dalam pencegahan penyakit kronis.

Tulisan diakhiri dengan suatu kesimpulan bahwa aktivitas jasmani yang teratur tidak harus secara terstruktur dilakukan oleh anak-anak dan orang dewasa, tetapi berbagai aktivitas jasmani yang

MEDIKORA Vol. II, No. 1, April 2006: 68 - 79. 
dilakukan dalam kehidupan sehari-hari dapat diupayakan untuk mencapai tingkat kesehatan.

Kata kunci: aktivitas jasmani, kesehatan

Memahami manusia bergerak memang merupakan suatu fenomena alami yang dapat dipelajari melalui berbagai disiplin ilmu. Gerak manusia telah menjadi kajian yang sangat menarik bagi Ilmu Keolahragaan. Keberadaan ilmu tersebut telah membuka mata manusia untuk memahami lebih dalam tentang kebermaknaan gerak. Benar adanya apabila kita setiap hari, setiap jam, setiap menit, bahkan setiap detik bergerak dengan menggunakan anggota tubuh. Gerak yang dilakukan mungkin dianggap hanya sebagai suatu aktivitas rutin sebagai bagian dari kehidupan, sehingga gerak yang lakukan tidak dapat meningkatkan kehidupan secara kualitas. Manusia sering menganggap kurang bermaknanya gerak yang dilakukan.

Gerak manusia sering dianalogikan dengan aktivitas jasmani. Manusia melakukan berbagai macam akvitas jasmani setiap harinya, dari bangun tidur sampai tidur lagi. Aktivitas jasmani yang kita lakukan itu seringkali tidak dapat memberikan makna penting di dalamnya. Hal ini dikarenakan bahwa manusia kurang memahami pentingnya beraktivitas jasmani dengan benar. WHO (2003: 1) mencatat bahwa sekitar $60 \%$ populasi dunia salah menafsirkan rekomendasi minimum 30 menit aktivitas jasmani yang berintensitas sedang. Bagi anak-anak, aktivitas jasmani yang dilakukan mungkin hanya sebatas di sekolah saja dan orang dewasa sama sekali kurang memperhatikan aktivitas jasmaninya karena sibuknya bekerja. Gregg Wilson (Keeling, 2006: 1) menyebutkan bahwa, "His biggest problem the United States faces is getting people to exercise”. Lebih lanjut Keeling (2006: 1) menjelaskan bahwa hanya sekitar $20 \%$ orang dewasa Amerika dianjurkan pada latihan tingkat aerobik dan sekitar $60 \%$ dianggap kegemukan.

Sebenarnya aktivitas jasmani yang dilakukan tidak harus merupakan program terstruktur, seperti pergi ke pusat kebugaran atau berlari setiap pagi, tetapi juga bekerja di halaman, berjalan ke pasar atau toko, menggunakan tangga dari pada tangga berjalan (elevator) semua akan meyumbang pada gaya hidup sehat. Orang dewasa yang aktif secara fisik, secara khusus akan lebih sedikit 
membutuhkan untuk pergi ke dokter dan lebih menikmati kualitas tidur yang baik, serta akan dapat meningkatkan kepuasan diri dan besarnya perasaan bebas. Hal ini memperlihatkan bahwa aktivitas jasmani yang dilakukan akan dapat membawa pada gaya hidup sehat dalam diri, sehingga gaya hidup sehat yang ingin dicapai oleh anak-anak maupun orang dewasa sebenarnya tidaklah sesulit yang dipikirkan.

Ketika anak-anak diharuskan melakukan aktivitas jasmani yang terstruktur itu merupakan sesuatu yang kontroversi. Anak-anak itu mudah terkena panas dan cedera persendian tulang. Persendian mereka masih tumbuh dan mungkin juga belum memiliki tingkat intelektualitas dan kedewasaan untuk beraktivitas secara terstruktur, sehingga yang paling cocok buat mereka adalah bermain yang secara fisik dapat mengembangkan koordinasi, kelincahan, dan keseimbangan. Bagi anak-anak, bergerak merupakan kebutuhan yang sangat vital bagi perkembangan dan pertumbuhan. Lain halnya dengan orang dewasa yang fisiologis tubuhnya akan mengalami penurunan metobalisme dan penurunan aktivitas jasmani. Orang dewasa sebenarnya mempunyai potensi yang sangat besar dalam mengembangkan dirinya melalui berbagai bentuk aktivitas jasmani. Peningkatan aktivitas jasmani dengan berpartisipasi dalam berbagai bentuk aktivitas jasmani dapat orang dewasa lakukan untuk berbagai tujuan, seperti: peningkatan kualitas kesehatan tubuhnya, pemeliharaan, membentuk tubuh yang ideal dan bernilai estetis.

Partisipasi masyarakat Indonesia dalam berbagai aktivitas jasmani masih kurang apabila dibandingkan jumlah penduduk yang ada. Hasil penelitian menunjukkan bahwa selama periode 1994-2000 terjadi penurunan tingkat partisipasi olahraga masyarakat. Angka partisipasi olahraga penduduk dari sebesar 35,3 \% pada tahun 1994 berkurang menjadi hanya sebesar 22,6 \% pada tahun 2000. Pada periode 2000-2003 terjadi gejala peningkatan partisipasi olahraga penduduk secara perlahan, yaitu dari sebesar 22,6 \% menjadi sebesar $25,4 \%$. Angka partisipasi olahraga penduduk perkotaan mencapai 32,1\%, sedangkan untuk daerah pedesaan sebesar 20,4 \%. Secara nasional juga ditunjukkan bahwa partisipasi olahraga penduduk laki-laki, (30,9\%) lebih tinggi dari penduduk perempuan (20,0\%) (Dirjen Olahraga dan BPS, 2004). Partisipasi masyarakat dalam olahraga didasari oleh motivasi dan tujuan tertentu, misalnya untuk menjaga kesehatan, prestasi, rekreasi/hiburan dan lainnya. Pada tahun

MEDIKORA Vol. II, No. 1, April 2006: 68 - 79. 
2003 dari keseluruhan penduduk yang berolahraga sebanyak 65,2\% melakukannya untuk menjaga kesehatan, kemudian sebesar 7,8 \% berolahraga untuk meningkatkan prestasi, dan 27,0\% lainnya melakukan olahraga untuk tujuan lainnya, seperti hiburan dan rekreasi (Dirjen Olahraga dan BPS, 2004).

\section{MAKNA KESEHATAN}

Kesehatan merupakan sesuatu yang cukup sulit untuk dimaknai. Hal itu berhubungan dengan pandangan seseorang terhadap arti kesehatan secara holistik. Balog (2005: 266) mengungkapkan bahwa para pendidik kesehatan memandang kesehatan sebagai suatu konsep yang subjektif, komprehensif, dan multidimensional, seperti halnya konsep dari WHO yang mendefinisikan kesehatan sebagai suatu keadaan fisik yang kompleks, mental, dan sosial yang baik dan tidak hanya ketiadaan penyakit atau kelemahan. Balog juga mendapati ada sesuatu yang ganjil, kebingungan, dan permasalahan tentang apa yang para pendidik kesehatan katakan dan pikirkan mengenai kesehatan.

Kesehatan memang mempunyai makna yang sangat filosofis bagi diri manusia. Memaknai kesehatan harus diawali dengan merealisasikan bahwa kesehatan secara logika dan realistis berada pada diri seseorang yang berarti keadaan fisik. Kesehatan bukan hanya sekedar konsep yang subjektif dan relatif yang dibuat dan didefinisikan dalam hubungannya dengan nilai-nilai budaya dan norma-norma sosial. Kesehatan harus menjadi bagian apa maknanya terhadap manusia dan hidup dalam kondisi manusia, sehingga Balog (2005: 269) mengemukakan "bealth is a physical well-being" or "bealth is a state of physical fitness". Sebenarnya kedua pernyataan tersebut didefinisikan oleh seberapa baiknya tubuh berfungsi secara alami dan seberapa baik fungsi alami ini memberikan kemampuan individu untuk mencapai sasaran fungsi pentingnya pada tingkat biologis dan kepribadian manusia.

Kesehatan memang mempunyai berbagai makna apabila manusia menggalinya secara filosofis. Hal ini dikarenakan adanya pandangan yang berbeda pula pada keberadaan tubuh manusia. Kesehatan memang berhubungan dengan keadaan tubuh manusia. Keadaan inilah yang memberikan arti pentingnya kesehatan bagi manusia. Ada yang beranggapan bahwa kesehatan hanya sematamata terjadi pada fisik manusia yang ditandai dengan tingkat kebugaran yang baik atau berfungsinya seluruh organ manusia secara baik. Pernyataan itu telah 
memisahkan raga dari jiwa yang secara utuh ada dalam diri manusia. Semboyan "Orandum est, ut sit mens sana in corpore sano" bukanlah suatu semboyan yang tidak bermakna. Kesehatan tubuh manusia seharusnya dipandang dari kedua segi antara raga dan jiwa. Tidaklah mungkin manusia memisahkan bagian fisik dengan jiwa yang berada di dalamnya.

\section{MANFAAT AKTIVITAS JASMANI}

Sebenarnya sudah jelas sekali bahwa aktivitas jasmani yang dilakukan akan membawa pada keuntungan pada kesehatan. Aktivitas jasmani yang dilakukan secara teratur mempunyai banyak manfaat bagi kesehatan. Sedikitnya melakukan aktivitas jasmani sedang selama 30 menit, seperti jalan cepat akan membawa pada berbagai manfaat kesehatan tersebut. Meningkatkan aktivitas jasmani, akan juga meningkatkan manfaatnya. Manusia tahu bahwa aktivitas jasmani dengan melakukan jalan, mengendarai sepeda, menari, dan bermain sederhana akan membuat dirinya lebih baik. Hal itu bukan hanya berpotensi untuk meningkatkan dan memelihara kesehatan yang baik, tetapi juga dapat membawa hal tersebut pada pentingnya manfaat sosial dan ekonomi. Aktivitas jasmani yang teratur bermanfaat bagi masyarakat dan bidang ekonomi dalam hal menurunkan biaya pemeliharaan kesehatan, meningkatkan produktivitas, penyelenggaraan sekolah yang lebih baik, mengurangi pekerja yang tidak masuk dan pergantian, serta meningkatkan partisipasi dalam olahraga dan aktivitas rekreasi.

WHO (2003: 3) menjelaskan bahwa secara umum aktivitas jasmani yang teratur dilakukan akan: (1) mengurangi risiko kematian sebelum waktunya, (2) mengurangi risiko kematian yang disebabkan penyakit jantung dan stroke dengan perbandingan 1:3 dari semua kematian, (3) mengurangi risiko peningkatan penyakit jantung dan kanker usus sampai $50 \%$, (4) mengurangi risiko peningkatan diabetes tipe II sampai $50 \%$, (5) membantu untuk mengurangi dan menjaga hipertensi, dengan efek 1:3 dari populasi penduduk dewasa dunia, (6) membantu untuk mengurangi dan menjaga osteoporosis, menurunkan risiko patah pinggul sampai $50 \%$ pada wanita, (7) mengurangi risiko peningkatan sakit punggung, (8) meningkatkan psikis yang baik, mengurangi stress, kecemasan, perasaanperasaan depresi dan kesepian, (9) membantu untuk memelihara atau mengontrol tingkah laku yang berisiko, teruatama pada anak-anak dan remaja, seperti kecanduan pada rokok, alkohol, dan berbagai zat yang berbahaya, diet yang

MEDIKORA Vol. II, No. 1, April 2006: 68 - 79. 
tidak sehat atau kekerasan, (10) membantu mengontrol berat badan dan menurunkan risiko menjadi gemuk sampai $50 \%$ dibandingkan dengan orang yang mempunyai gaya hidup statis, (11) membantu membentuk dan memelihara kesehatan tulang-tulang, otot-otot, dan persendian dan membuat orang yang sakit menahun dan kondisi lumpuh untuk meningkatkan stamina mereka, (12) dapat membantu memanage kondisi yang sakit, seperti sakit punggung dan sakit persendian lutut. Manfaat aktivitas jasmani yang dilakukan dapat digambarkan sebagai berikut:

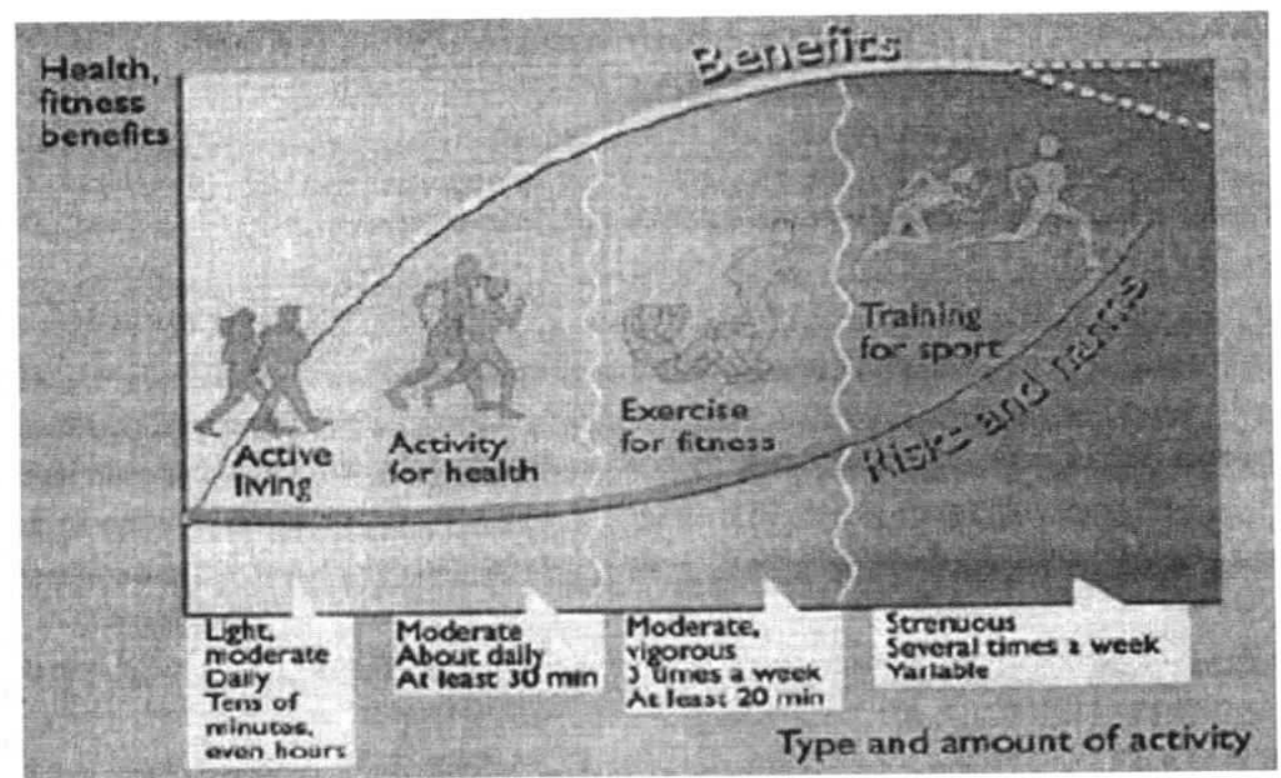

Gambar 1. Aktivitas Jasmani dan Manfaatnya

Sumber: WHO (2003: 3)

\section{AKTIVITAS JASMANI YANG DIBUTUHKAN UNTUK PENGEMBANGAN DAN PEMELIHARAAN KESEHATAN}

Ada beberapa rekomendasi yang diberikan WHO berhubungan dengan pengembangan dan pemeliharaan kesehatan. Keuntungan Kesehatan yang banyak diperoleh melalui aktivitas jasmani yang berintensitas sedang setiap hari secara kumulatif selama kurang lebih 30 menit (WHO, 2003: 3-4). Aktivitas jasmani tingkat ini dapat dijangkau melalui aktivitas jasmani dan gerak tubuh yang luas 
dalam kehidupan sehari-hari, seperti: berjalan untuk bekerja, menggunakan tangga, berkebun, menari, dan juga berbagai olahraga rekreasi dan pengisi waktu luang. Keuntungan kesehatan tambahan yang banyak diperoleh dengan giat melakukan aktivitas jasmani berintensitas sedang setiap hari dengan durasi yang cukup lama (WHO, 2003: 3-4), seperti: anak-anak dan remaja membutuhkan aktivitas jasmani tambahan selama 20 menit 3 kali seminggu, kontrol berat badan memerlukan aktivitas jasmani yang sedang sekitar 60 menit setiap hari. Rekomendasi ini sangat sederhana dan dapat dilakukan oleh semua orang di seluruh dunia, sehingga WHO menyarankan aktivitas jasmani tersebut dilakukan dengan memasukkannya dalam kehidupan sehari-hari.

Wilson (Keeling, 2006: 1) menyarankan bahwa untuk membakar kalori dan memperoleh manfaat kardivaskuler, orang dewasa harus melakukan latihan minimal 20 - 30 menit, 3 sampai 4 kali seminggu pada $60-80 \%$ denyut nadi maksimum. Sebuah lembaga informasi kesehatan untuk wanita di Amerika Serikat juga menyebutkan bahwa, (1) untuk mengurangi risiko penyakit kronis setidaknya 30 menit melakukan aktivitas jasmani intensitas sedang, lebih tinggi dari aktivitas biasa di tempat bekerja atau di rumah dalam sebagian besar hari seminggu, (2) untuk membantu mengatur berat badan dan pemeliharaan secara bertahap, serta gangguan kesehatan dari berat badan, melakukan sekitar 60 menit aktivitas jasmani intensitas sedang-berat dalam sebagian besar hari daalam seminggu, (3) untuk mengurangi berat badan, dapat melakukan aktivitas jasmani intensitas sedang 60 - 90 menit dengan tidak memasukan kalori melebihi dari yang dipersyaratkan (National Women's Health Information Center, 2005: 2). Mereka juga menyarankan adanya pemanasan sekitar 5-10 menit sebelum latihan yang bertujuan untuk mencegah terjadinya cedera pada persendian dan otot. Aktivitas jasmani yang berintensitas sedang yang dianjurkan dalam kehidupan sehari-hari dapat dilihat pada gambar 2.

Hal ini sangatlah penting untuk memberikan anak-anak dan orang dewasa kesempatan dalam melakukan aktivitas jasmani yang teratur pada bagian kehidupan sehari-harinya. Berpartisipasi dalam berbagai macam dan jumlah aktivitas jasmani selama masa anak-anak dan dewasa dapat memberikan manfaat penting bagi kesehatan. Patrick K., Spear B., Holt K., Sofka D (2001: 9) menjelaskan aktivitas jasmani dapat membantu meningkatkan hasil kesehatan anak-anak dan orang dewasa. Aktivitas aerobik (lari jauh, berenang, bersepeda)

MEDIKORA Vol. II, No. 1, April 2006: 68 - 79. 
Washing and waxing a car for 45-60 minutes

Washing windows or floors for 45-60 minutes

Playing volleyball for 45 minutes

Playing touch football for $30-45$ minutes

Gardening for 30-45 minules

Wheeling self in wheelchair for 3040 minutes

Walking $13 / 4$ miles in 35 minutes ( $20 \mathrm{~min} / \mathrm{mile}$ )

Basketball (shooting baskets) for 30 minutes

Bicycling 5 miles in 30 minutes

Dancing fast (social) for 30 minutes

Pushing a stroller $1 \frac{1}{2}$ miles in 30 minutes

Raking leaves for 30 minutes

Walking 2 miles in 30 minutes ( $15 \mathrm{~min} / \mathrm{mile}$ )

Water aerobics for 30 minutes

Swimming laps for 20 minutes

Wheelchair basketball for 20 minutes

Basketball (playing a game) for 15-20 minules

Bicycling 4 miles in 15 minutes

Jumping rope for 15 minules

Rumning $1 \frac{1}{2}$ miles in 15 minutes ( $10 \mathrm{~min} / \mathrm{mile}$ )

Shoveling snow for 15 minutes

Less Vigorous,

More Time

Stairwalking for 15 minutes

Gambar 2. Contoh Aktivitas Jasmani Intensitas sedang dalam Kehidupan Sehari-hari Sumber: The President's Council On Physical Fitness And Sports (1996: 1)

sangat baik bagi pengeluaran kalori. Aktivitas jasmani seperti: lompat tali, berjalan, bermain sepakbola atau bola basket akan memaksa anak-anak dan orang dewasa untuk menggerakkan tubuhnya sendiri. Aktivitas jasmani (berlari, bersepeda, berenang) yang dilakukan selama 30 menit tiga kali seminggu akan meningkatkan kebugaran kardiovaskuler (kapasitas kardiovaskuler, kekuatan, dan daya tahan aerobik atau kebugaran), selain itu juga dapat menurunkan tekanan darah anak-anak dan orang dewasa yang mengidap tekanan darah tinggi (Hypertension) (Patrick K., Spear B., Holt K., Sofka D., 2001: 6). Aktivitas jasmani dapat meningkatkan kebugaran otot yang dapat menurunkan risiko cedera pada anak-anak dan orang dewasa. 


\section{PENCEGAHAN PENYAKIT KRONIS MELALUI AKTIVITAS JASMANI}

Berbagai penyakit kronis yang diserita manusia dewasa salah satunya adalah diakibatkan oleh kurangnya bergerak atau aktivitas jasmani. Peningkatan aktivitas jasmani juga berhubungan dengan aturan pemeliharaan kesehatan lainnya dalam menurunkan tisiko penyakit kronis pada orang dewasa, seperti: makan makanan yang sehat, mendapatkan dan memelihara berat badan sehat, dan menghindari rokok. Penyakit kronis yang diidap oleh orang dewasa biasanya juga berhubungan dengan terus bertambahnya umur mereka. Pencegahan dapat dilakukan apabila manusia dapat melakukan berbagai aktivitas jasmani secara teratur dalam kehidupan sehari-hari.

Osteoporosis merupakan penyakit yang menyerang tulang. Terjadinya osteoporosis akan dapat mengakibatkan risiko patah tulang pada anak-anak dan orang dewasa. Aktivitas jasmani yang teratur akan membentuk tingginya kepadatan tulang pada anak-anak dan orang dewasa, selain itu juga dapat memelihara kepadatan ujung tulang pada orang dewasa. Peningkatan mineral tulang dan pembentukan tulang yang kuat dengan melakukan aktivitas jasmani yang menahan berat badan, seperti: lompat tali, berjalan, bermain sepakbola, dan bolabasket, dan juga mengonsumsi kalsium secara optimal (Patrick K., Spear B., Holt K., Sofka D., 2001: 6).

Sudah diketahui bahwa aktivitas jasmani sangat penting untuk memperoleh dan memelihara berat badan yang sehat. Perlu ada kombinasi dengan campur tangan keluarga dan penurunan kalori yang masuk dengan aktivitas jasmani yang menghasilkan penurunan signifikan pada meratanya anak-anak dan orang dewasa yang kegemukan. Mengurangi tingkah laku yang hanya "diam" (seperti; nonton TV, bermain komputer) dengan intervensi aktivitas yang penting untuk menurunkan tingkat kegemukan. Menurut Patrick K., Spear B., Holt K., Sofka D. (2001: 7) kegemukan pada anak-anak dan orang dewasa merupakan faktor risiko timbulnya penyakit diabetes mellitus tipe 2 .

Hypertension (tekanan darah yang tidak normal) menyebabkan stroke, gagal ginjal, penyakit jantung koroner, penyakit jantung bawaan, penyakit pembuluh darah pada orang dewasa. Semua kondisi tersebut berhubungan dengan kepentingan bypertension, yang biasanya turun menurun dan seringkali berkembang pada masa anak-anak. Aktivitas jasmani yang teratur secara subtansial dapat

MEDIKORA Vol. II, No. 1, April 2006: 68 - 79. 
menurunkan tekanan darah sistol dan diastol pada orang dewasa yang bypertension. Hal itu memperlihatkan bahwa aktivitas jasmani yang teratur dapat juga menurunkan tekanan darah pada anak-anak dan orang dewasa.

Aktivitas jasmani aerobik yang teratur ditemukan telah meningkatkan kadar lemak darah, terutama meningkatkan High-Density Lipoprotein Cholesterol (HDL-C). Tingkat HDL-C yang tinggi dihubungkan dengan penurunan risiko artheosclerosis (Patrick K., Spear B., Holt K., Sofka D., 2001: 8). Strategi pencegahan byperlipidemia termasuk melalui aktivitas jasmani aerobik. Sebenarnya pengaruh aktivitas jasmani pada tingkat lemak tubuh anak-anak dan orang dewasa belum jelas. Tingkat HDL-C pada olahragawan lebih besar daripada anak-anak dan orang dewasa yang tidak melakukan aktivitas jasmani secara teratur (Patrick K., Spear B., Holt K., Sofka D., 2001: 8).

Selain penyakit-penyakit fisik tersebut di atas, aktivitas jasmani juga berpengaruh pada kesehatan mental. Hal ini dikarenakan bahwa tubuh manusia memang bukan merupakan dualisme, tetapi harus dilihat secara holistik sebagai suatu kesatuan yang utuh. Aktivitas jasmani jelas akan berpengaruh secara menyeluruh pada diri manusia yang melakukannya. Aktivitas jasmani yang teratur sangat berpotensi untuk meningkatkan kesehatan mental anak-anak dan orang dewasa, seperti meningkatkan harga diri mereka dan menurunkan tingkat kecemasan dan stress mereka. Berpartisipasi dalam aktivitas jasmani yang teratur muncul untuk mempertinggi harga diri dan menurunkan gejala-gejala depresi dan kecemasan pada anak-anak dan orang dewasa yang emosinya tidak teratur atau keterbelakangan mental. Siegel (2006: 1) mengungkapkan bahwa secara umum ada kesatuan yang positif antara prestasi akademis dan pekerjaan dalam aktivitas jasmani. Dampak ini mungkin ditengahi oleh tingginya konsentrasi, daya ingat, dan perlakuan kelas.

\section{KESIMPULAN}

Aktivitas jasmani mempunyai hubungan yang sangat erat kaitannya dengan peningkatan dan pemeliharaan kesehatan. Aktivitas jasmani yang dilakukan sebenarnya tidak perlu secara formal terstruktur dengan berbagai metode latihan, tetapi hal itu dapat dilakukan dengan cara menggunakan berbagai aktivitas jasmani yang sering digunakan dalam kehidupan sehari-hari. Hubungannya dengan makna kesehatan itu sendiri aktivitas jasmani harus dapat bermanfaat 
bagi keadaan tubuh manusia secara utuh. Manfaat yang didapat dari melakukan berbagai aktivitas jasmani bukan hanya sekedar adanya peningkatan dan pemeliharaan tubuh secara biologis, tetapi harus bermanfaat juga bagi peningkatan kepribadian seseorang.

Secara nyata memang manusia menilai kebermanfaatan aktivitas jasmani lebih pada kontribusinya terhadap tingkat kesehatan tubuh secara biologis terutama pencegahan penyakit-penyakit biologis kronis tubuh manusia. Kenyataan lain mengungkapkan bahwa aktivitas jasmani yang dilakukan juga akan berpengaruh pada kesehatan mental seseorang. Pada anak-anak sekolah aktivitas jasmani yang dilakukan secara teratur dapat meningkatkan prestasi akademisnya di sekolah, karena kemampuan otak meningkat setelah anak melakukan berbagai aktivitas jasmani itu.

\section{DAFTAR PUSTAKA}

Balog, Joseph E. (2005). "The Meaning of Health". American Journal of Health Education; Sep/Oct 2005; 36, 5; Proquest Education Journals Pg. 266.

Dirjen Olahraga dan BPS. (2004). Sport Development Index (SDI) Nasional Tahun 2004. Jakarta. Direktorat Jenderal Olahraga Departemen Pendidikan Nasional.

Keeling, Libby. (2006). “Physical Activity: If You're Moving, It'Ll Be Easier to Leave Bad Health Habits Behind". Available online at http://www.brightfutures.org/ physicalactivity/pdf.

National Women's Health Information Center. (2005). Physical Activity (Exercise). U.S. Department of Health and Human Services, Office on Women's Health.

The President's Council on Physical Fitness and Sports. (1996). Physical Activity and Health. Atlanta, Georgia. Centers for Disease Control and Prevention. National Center for Chronic Disease Prevention and Health Promotion. U.S. Department of Health and Human Services.

Siegel, Donald. (2006). "The Effects of Physical Activity on the Health and Well-Being of Youths". Journal of Physical Education, Recreation \& Dance; Jan 2006; 77, 1; ProQuest Education Journals pg. 11.

World Health Organization. (2003). Health and Development through Physical Activity and Sport. Geneva, Switzerland: The WHO Document Production Services.

MEDIKORA Vol. II, No. 1, April 2006: 68 - 79. 
Patrick K, Spear B, Holt K, Sofka D, eds. (2001). Bright Futures in Practice: Physical Activity. Arlington, VA: National Center for Education in Maternal and Child Health. 